\title{
Pelatihan praktik melukis teknik fresco bagi siswa Kelas X di Sekolah Menengah Atas Negeri 14 Makassar
}

\author{
Muh. Saleh Husain ${ }^{1}$, Andi Nur Maida ${ }^{2}$, Benny Subiantoro ${ }^{3}$ \\ ${ }^{1,2,3}$ Fakultas Seni dan Desain, Universitas Negeri Makassar
}

\begin{abstract}
The material of the learning process of the theory of fine arts education and the practicum of fine arts education, whose behavior to directed at the process of serving the concepts of aesthetic concepts, creativity and work, adjusted to the level of ability of the students themselves. The connection in this case, to avoid the passivity of students during the learning process of art education, through the presentation of educational media implemented by the teacher will be a motivation for creative thinking to apply freedom to express their feelings and realize real work increating works of art in accordance with the assignment of structured subject matter from the teacher. The tendency to words increasing teaching in fine arts education will benefit from being presented informal academic instituions that are applied in Makassar public High School 14, regarding the learning process in an innovative direction, both in the form of basic theoretical offerings and the practice of creating fine art is pretty much marked through a form of teaching process that gives room for creativity, explanation, learning to work on Fresco techniques, which of course begins with the practice of learning to draw sketches that are applied to Makassar14 Senior High School students, so students will experience a change from not knowing to being know, through growth in attitudes and growth in thinking more creative and intelligent.
\end{abstract}

Keywords: fresco techniques, students, fine arts

\section{PENDAHULUAN}

Setelah mempelajari dengan seksama, mengenai belajar pendidikan seni rupa di Sekolah Menengah Atas Negeri 14 Makassar, melalui alat bantu mengajar sebagai media pembelajaran pendidikan seni rupa, diharapkan guru dan siswa akan memperoleh sejumlah kompetensi dasar untuk memudahkan terapan di dalam proses belajar mengajar. Proses pembelajaran pendidikan seni rupa sebagai usaha mencapai tujuan pendidikan berlangsung dalam suatu proses pembelajaran untuk mengalihkan pengetahuan yang erat dengan kandungan estetika, artistik, sikap dan keterampilan terhadap peserta didik di Sekolah Menengah Atas Negeri 14 Makassar, kegiatan pembelajaran seni rupa di Sekolah tersebut juga disajikan adanya keseimbangan sajian materi proses pembelajaran teori pendidikan seni rupa dan praktikum pendidikan seni rupa, yang gerak prilakunya diarahkan pada metode proses sajian konsepkonsep estetika, berkreativitas dan berkarya, disesuaikan dengan tingkat kemampuan peserta didik itu sendiri.
Kaitannya dalam hal ini, untuk menghindari kepasifan siswa-siswa selama dalam proses belajar pendidikan seni rupa, melalui sajian media pendidikan yang diterapkan oleh guru akan menjadi motivasi berfikir kreatif untuk menerapkan kebebasan eksplorasi dan kebebasan mengekspresikan perasaannya dan mewujudkan hasil karya nyata di dalam mencipta karya-karya seni rupa yang sesuai penugasan materi pelajaran terstruktur dari gurunya.

Kecenderungan terhadap meningkatnya pengajaran pendidikan seni rupa akan memperoleh manfaatnya yang disajikan pada lembaga pendidikan formal secara akademik yang diterapkan di Sekolah Menengah Atas Negeri 14 Makassar, mengenai proses pembelajaran yang arahnya inovatif, baik dalam bentuk sajian teori mendasar dan praktik berkarya seni rupa cukup banyak ditandai melalui bentuk proses pengajaran yang memberi ruang untuk berkreativitas, bereksplorasi, yang diterapkan terhadap siswa-siswa Sekolah Menengah Atas Negeri 14 Makassar, sehingga siswa-siswa akan mengalami perubahan dari tidak tahu menjadi tahu, melalui pertumbuhan pada 
sikap prilaku dan pertumbuhan berpikirnya semakin kreatif dan cerdas. Maka menggambar bentuk dasar atau skets menjadi dasar utama untuk menyelesaikan berkarya lukis, baik lukisan itu diterapkan di atas kertas, di atas kain (kanvas), di atas permukaan dinding (lukis teknik fresco).

Melalui sajian ulasan penulisan modul belajar mengenal pendidikan seni rupa untuk pelaksanaan Pengabdian Pada Masyarakat Universitas Negeri Makassar, penulis terlebih dahulu menjelaskan teori tentang pengertian terapan teknik seni lukis. Seni lukis yaitu karya yang dihasilkan melalui goresan warna yang relatif berukuran lebar, yang dihasilkan menggunakan alat kuas, pisau palet, tabung pilox, telapak tangan dan jari tangan, dengan menerapkan bahan berbagai pewarna. (Salam, 2000). Seni Lukis Fresco yaitu teknik melukis pada dinding dengan menimpakan pigmen pada plaster dinding yang baru dilapisi, kemudian definisi ini sedikit berubah karena Leonardo da Vinci memperkenalkan teknik baru dengan menimpakan pigmen warna kepada lapisan yang telah kering dengan sedikit modifikasi (Anonim, 2018).

\section{METODE PELAKSANAAN}

Pelaksanaan workshop pelatihan tentang belajar menggambar sketsa dan dilanjutkan pada berkarya lukis teknik Fresco yang disajikan pada Siswa SMAN 14 Makassar dalam sajian Pengabdian Pada Masyarakat diuraikan sebagai berikut.

Instruktur menyajikan materi workshop belajar teori dan praktik pada peserta PKM FSD UNM Makassar, yaitu para siswa Sekolah Menengah Atas Negeri 14 Makassar setelah disajikan materi belajar menggambar sketsa bentuk bebas dan bentuk huruf, dapat mengetahui metode mudahnya belajar menggambar dan menulis huruf balok, mengenai menggambar diawali membuat bentuk angka-angka nol sampai sembilan, sedangkan menulis huruf balok, diawali membuat bentuk huruf yang terlebih dahulu dibuat huruf kapital huruf kecil, huruf yang dibuat diawali dari huruf awal dari masing-masing nama siswa. Sebagai pengantar sebelum menggambar dan menulis huruf diperkenalkan karakter garis, yang mana garis terdiri atas tiga macam karakter yaitu garis lurus, garis lengkung dan garis patah. Jika mengamati bentuk arah garis dari angka nol sampai angka sembilan, maka masing-masing mengarah pada bentuk karakter garis lurus, patah dan lengkung.

\section{HASIL DAN PEMBAHASAN}

Hasil belajar siswa diperlihatkan sebagai capaian hasil belajar dapat dilihat gambar foto hasil aktivitas siswa belajar menggambar dan menulis huruf, sebagai berikut.

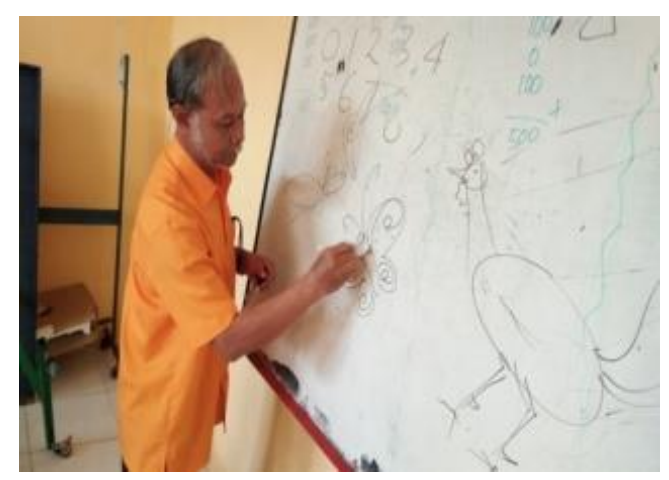

Gambar 1. Instruktur memperagakan menulis aksara

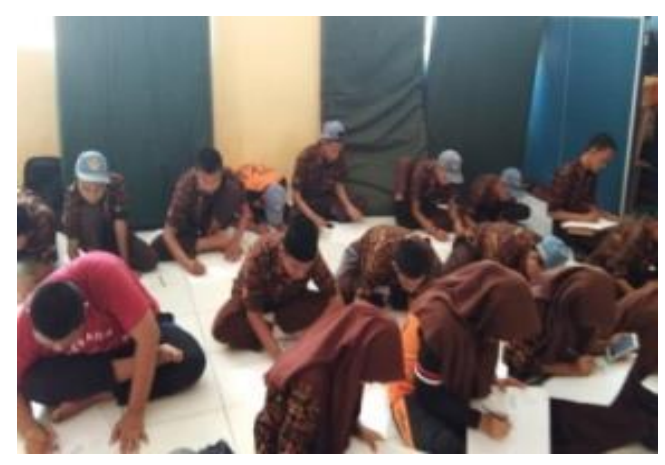

Gambar 2. Siswa tekun belajar menggambar

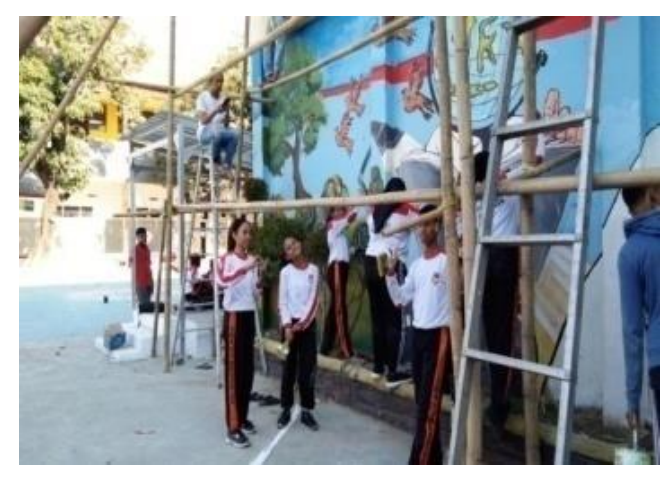

Gambar 3. Karya Nabigha Khabilah Kelas X IPS 3 


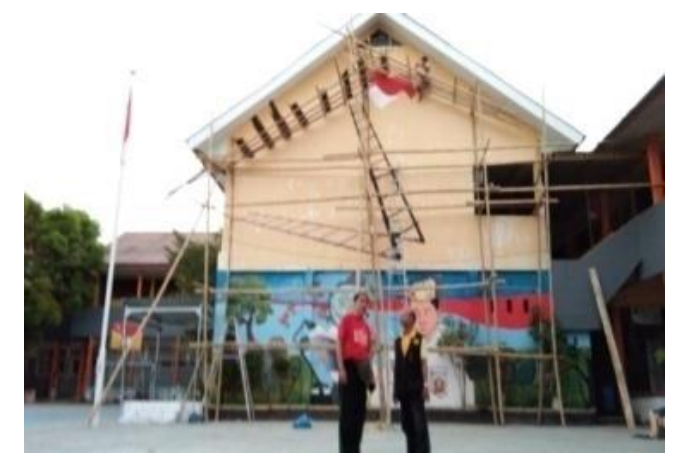

Gambar 4. Siswa praktik melukis teknik Fresco, dua instruktur di depan gedung dan karya lukis

\section{KESIMPULAN}

Berdasarkan uraian pada setiap bab sebelumnya, maka dapat disimpulkan sebagai berikut: Pelatihan yang dilaksanakan di Sekolah Menengah Atas Negeri 14 Makassar dapat menerapkan pengembangan media pendidikan seni rupa tingkat
Sekolah tersebut dan dapat berperan sebagai landasan utama untuk mudahnya proses pembimbingan, melatih dan mengembangkan kemampuan kognitif, afektif dan psikomotorik secara mendasar dan untuk mencapai tingkat emosional serta spiritual di dalam memperoleh hasil berbagai materi terapan model-model pembelajaran aktif, inovatif, kreatif, serta dapat membangkitkan daya minat belajar mata pelajaran Seni Budaya (Seni Rupa) yang menyenangkan.

\section{DAFTAR PUSTAKA}

Salam, Sofyan, 2000. Seni Rupa Mimesis dan Modern/ Kontemporer di Sulawesi Selatan (Sebuah Pengantar Tentang Perjalanan dan Persoalannya), DKSS Makassar, Makassar.

Anonim, 2018. https//www.dicto id.teknik melukis al fresco. Diakses pada tanggal 3 April 2018. 